DOI: $10.17976 / j p p s / 2019.06 .11$

\title{
ИНСЦЕНИРОВАНИЕ ПОЛИТИЧЕСКОЙ РЕАЛЬНОСТИ
}

\section{B.C. Сорокина}

СОРОКИНА Вероника Сергеевна, аспирантка кафедры международной журналистики МГИМО МИД России, Москва, email: vero-nika-vika@mail.ru

Сорокина В.С. Инсценирование политической реальности. - Полис. Политические исследования. 2019. № 6. C. 145-158. https://doi.org/10.17976/jpps/2019.06.11

Статья поступила в редакцию: 30.05.2019. Принята к публикации: 28.08.2019

\begin{abstract}
Аннотация. Термин “инсценирование”, возникший в 1820-1830-х годах в рамках театрального лексикона, приобрел особое значение с появлением новых медиа, имеющих такие особенности, как цифровой формат, интерактивность и мультимедийность. Сегодня это понятие отражает вторжение принципов театральности как в информационную повседневность каждого человека, так и в глобальные политические процессы. Пользуясь методологией, разработанной классиками политической социологии и коммуникологии (Ж. Бодрийяр, Ю. Хабермас, М. Маклюэн) и современными исследователями (Э. ФишерЛихте, Т. Мейер, К. Шиха), автор показывает, как в результате инсценирования размываются границы между реальным и представляемым, что впоследствии может применяться в целях манипулирования общественным мнением. В статье рассматриваются различные аспекты феномена инсценирования и его особенности на современном этапе, а также анализируются процессы, создающие условия для популяризации и повсеместного использования инсценирования. Автор приходит к выводу, что на фоне роста иррациональности и неопределенности в постнеклассическом обществе и усиления роли масс в формировании информационной повестки именно они, а не отдельные акторы и правящие элиты, выступают основным “заказчиком” инсценируемой реальности, а затем и ее потребителем. При этом нивелировать негативные последствия инсценирования становится все сложнее, поскольку оно не имеет единого источника и не может контролироваться.
\end{abstract}

Ключевые слова: инсценирование, символическая политика, политическая реальность, информационное пространство, СМИ.

Знания в современном мире приобретают все более хаотичный и неструктурированный характер, а критерии, по которым человек мог бы отбирать информацию, теряются и размываются [Бауман 2008]. В этих условиях ключевыми факторами восприятия становятся: 1) скорость передачи данных, сокращение отрезка времени между событием и получением сообщения об этом событии; 2) количество ежедневно получаемых реципиентом сообщений; 3) искажение смыслов, происходящее намеренно или случайно в процессе создания и передачи сообщения.

Информация о событии, которую получает человек, обрастает таким количеством дополнительных деталей, контекстов и мнений, что из новости может превратиться в симулякр события, связанный скорее с освещением события в СМИ и его обсуждением в интернет-пространстве, чем с реальными фактами и данными. В результате события “функционируют как набор знаков, предназначенных исключительно для своего повторения как знаков, а вовсе не для своей ‘реальной’ цели” [Бодрийяр 2015: 33]. В этом случае общая картина 
мира может искажаться настолько, что обсуждение гиперболизированных СМИ явлений выходит за рамки будничных дискуссий и переносится на официальный уровень, влияя на принятие политических решений.

Стоит разграничивать понятия “инсценирование” и “пропаганда": если пропагандист преследует в первую очередь политические цели, то для производителя инсценируемого контента (при условии его наличия) целью обычно выступает привлечение внимания и расширение аудитории. Инсценированное событие способно возникнуть без определенного заказчика или источника, так как может стать непредвиденным результатом деятельности ряда СМИ или акторов.

Инсценирование нельзя свести к стереотипам, фейкам, эффекту фрейминга или к симулякрам, поскольку каждое из этих понятий отражает скорее один из возможных результатов инсценирования. Стереотипность здесь проявляется в установлении прочной смысловой связи, однако она присуща лишь успешному инсценированию, надолго закрепляющему созданный образ в сознании зрителя. Фейки ${ }^{1}$ и фрейминг [Entman 1993] могут быть характерным, но необязательным следствием инсценирования события, поскольку искажения и расстановка смысловых акцентов не всегда преднамеренны. Наконец, не все плоды инсценирования можно считать симулякрами, так как сосуществуют копии как реальных явлений, так и несуществующих. Говоря о таких понятиях, как "постправда" [Чугров 2017] и "гиперреальность" [Бодрийяр 2015], следует подчеркнуть, что они охватывают более масштабные явления, а инсценирование представляет собой только их структурную часть,

146 хотя и неотъемлемую. Инсценирование давно использовалось как инструмент политики, однако только формирование “искривленного политического информационного пространства” постправды [Чугров 2017] привело к его повсеместному распространению.

\section{ТЕАТРАЛИЗАЦИЯ И ИНСЦЕНИРОВАНИЕ. ОПЕРАЦИОНАЛИЗАЦИЯ ПОНЯТИЙ}

Согласно наблюдениям исследователей [Meyer 2000b; Fischer-Lichte 2001; Schicha 2003], принципы представления материала в СМИ сходны с теми средствами, при помощи которых театр достигает своего эффекта. Аудиовизуальные медиа воздействуют на зрителя комплексно, объединяя язык, изображение, движения, жесты, мимику и интонации, тем самым обусловливая одновременно визуализацию, персонализацию и ритуализацию контента. За счет использования видеоряда (даже архивного) в материалах телевидения, а теперь и в мультимедийном онлайн-контенте создается иллюзия присутствия и актуальности, достигается практически тот же эффект “трех единств”, что и в классической драматургии. Несколько временных отрезков и локаций встречаются в одном медийном сюжете, и тем самым производят впечатление реальности демонстрируемого. Когда данными преимуществами информационного пространства стали пользоваться политики и другие публичные личности, такие выражения, как "политическая арена", “политическое закулисье”, “авансцена", “жонглирование заявлениями” и “марионетки” приобрели уже не переносный, но буквальный смысл.

\footnotetext{
${ }^{1}$ Фейк - что это такое? Определение, значение, перевод. - Что это такое? URL: https://chto-etotakoe.ru/fake (accessed 28.09.2019).
} 
“Театрализация”, однако, отличается от инсценирования. Представление определенной ситуации на сцене подразумевает наличие этой самой сцены [Schicha 2003: 11], видимой зрителю. Аудитория понимает, что перед ней персонажи, а не реальные личности, и они действуют по тем правилам, которые задал организатор постановки. Инсценирование функционирует по тем же принципам, однако "мимикрирует" под реальность.

Наш анализ понятия “инсценирование” опирается на исследования феноменов, сходных или смежных с инсценированием, которые нечасто оказывались в фокусе внимания ученых. Тем не менее рассматриваемые в статье труды, по мнению автора, отражают сущность тех или иных аспектов инсценирования, в то время как во многих иных работах оно упоминается лишь вскользь, без какого-либо анализа. Наиболее детально разбирают инсценирование немецкие исследователи Т. Мейер, К. Шиха и М. Эдельман, изучающие этот феномен как инструмент управления общественным мнением и метод отправления власти.

Необходимость более широкого употребления термина “инсценирование” как глобального феномена становится очевидной, если обратиться к ранним трудам таких ученых, как У. Бек и Ж. Бодрийяр. Инсценирование у них предстает не как результат действий отдельных акторов, а как следствие идущих в обществе процессов. Чтобы провести границу между двумя подходами, следует разделить инсценирование "на микроуровне" и "на макроуровне", а также разграничить коммуникационный, социоантропологический и политологический аспекты.

Поскольку феномен инсценирования часто упоминается в исследованиях по политической социологии для выстраивания базы смежных концепций, можно сделать вывод, что он достоин более тщательного изучения, особенно на фоне трансформации информационного пространства. Автор ставит задачу проанализировать понятие "инсценирование" с учетом различных аспектов гуманитарного знания.

Термин “инсценирование” возник в 1820-1830-х годах в качестве производного от французского термина “мизансцена" (mise en scène), который появился незадолго до этого [Fischer-Lichte 1998: 82]. Как отмечает Фишер-Лихте, изначально инсценирование обозначало организацию труппы и художественного материала для представления драматического произведения. В дальнейшем понятие получило столь широкое распространение, что стало относиться ко всем процессам, целью которых была презентация какого-либо события под определенным углом зрения. Так, в качестве инсценирования рассматривались все виды культурного перформанса, такие как ритуалы, церемонии, судебные заседания, политические собрания, спортивные мероприятия и т.д.

Инсценирование в качестве медиаопосредованного политического представления является воплощением символической политики [Hoffmann, Sarcinelli 1999: 732]. Под символической политикой в узком смысле понимается публичное представление политика в долгосрочной борьбе за приобретение и удержание властных позиций [Kaase 1998]. Однако в нашей работе используется более широкое понимание символической политики как деятельности, “направленной на производство и продвижение/навязывание определенных способов интерпретации социальной реальности в качестве доминирующих" [Малинова 2012]. Кроме того, символическая политика, 
а вместе с ней и инсценирование, рассматриваются автором как специфический аспект "реальной" политики.

Обзор истоков инсценирования обычно включает эпизоды, произошедшие до появления медиа в современном понимании и имевшие целью произвести на публику эффект. Э. Фишер-Лихте описывает события XII в. - борьбу за папский престол Иннокентия II и Анаклета II [Fischer-Lichte 2001: 10], а П. Бурке отмечает схожие примеры во время правления Людовика XIV [Burke 1993: 158]. Авторы считают, что наиболее важными функциями исторических политических постановок в прошлом были: (1) установление обязательного характера, надежности и предсказуемости политических субъектов, (2) легитимация претензий на власть и (3) закрепление в обществе ценностей с помощью создания идентификационного потенциала.

\section{ХАРАКТЕРИСТИКА ПОНЯТИЯ: КОММУНИКАЦИОННЫЙ АСПЕКТ}

Согласно Толковому словарю русского языка под ред. Д.Н. Ушакова, слово “инсценировать" имеет два значения: прямое - "переделывать в драму, приспособить литературное или иное произведение для постановки на сцене”; переносное - “изображать, устраивать что-либо с каким-либо намерением, стремясь внушить иллюзию подлинности" 2 . В коммуникологии закрепились два аспекта понятия: художественно-эстетический и социально-психологический, однако в практике политической коммуникации грань между ними стирается. С одной стороны, любой политический контент адаптируется для “постановки на сцене" (в данном случае в СМИ). С другой стороны, во многих случаях целью инсценирования может быть не обман и попытка выдать одно событие за другое, а драматургический эффект, привлекающий внимание аудитории.

М. Эдельман проводит границу между используемыми приемами и тем экспрессивным воздействием, которое они оказывают [Edelman 1976: 5]. Т. Мейер предлагает рассматривать инсценирование и как аналитическое, и как ценностно-нейтральное понятие - как набор техник или инструментарий [Meyer 2001: 49], а Фишер-Лихте считает инсценирование "специфическим способом использования знаков в процессе производства медиаматериала" [Fischer-Lichte 2001: 20]. Тем не менее в большинстве случаев понятием "инсценирование" обозначают своеобразное театрализованное представление, имеющее манипулятивный характер и вводящее аудиторию в заблуждение, отвлекающее ее от ключевой проблемы. По мнению К. Шихи и Р. Онтрупа, инсценирование - это просчитанный выбор, организация и структурирование средств выразительности с целью воздействия на публику [Schicha, Ontrup 1999: 7]. Важно, что все попытки перенести понятие из сферы театра на социальные отношения подразумевают целенаправленное создание собственного контекста, чтобы повлиять на зрителя. Так, с помощью термина "инсценирование" зачастую описывают только процесс, когда политики и сотрудники их штабов создают события для освещения в СМИ и драматически обыгрывают их.

Для медийного представления масштабных явлений неизбежно используются методы воссоздания реальности посредством образов, идентично методам инсценирования. Любой дискурс включает в себя темы, процессы и сюжетные линии, а значит, не может строиться без частичной смысловой редукции со-

\footnotetext{
2 Толковый словарь русского языка. В 4 т. Под ред. Д.Н. Ушакова. М.: Сов. энцикЛ.: ОГИЗ, $1935-1940$. URL: https://slovar.cc/rus/ushakov/403361.html (accessed: 20.09.2019).
} 
держания за счет выборочного сужения темы до более простых и очевидных форм. Кроме того, помимо неизбежной трансформации материала в процессе его обработки журналисты сами преобразовывают политические явления, используя просчитанные стратегии и тщательно отобранные смысловые контексты в концентрированной форме, пытаясь вписать то или иное событие в “продуманную комбинацию знаковых систем" [Meyer 2001: 49]. Примером может стать широкий спектр форм подачи медиаконтента, например, создание определенного образа, “концентрация” события, нарративов, символической мини-драмы, вплоть до специфической визуальной обработки.

Можно выделить три инсценировочных уровня, через которые проходит политический контент в офлайн-СМИ: 1) уровень повседневной коммуникации, которая может осуществляться посредством “театральных техник” (ролевое поведение, в частности); 2) публичное инсценирование со стороны политиков; 3) адаптация контента сотрудниками СМИ для конкретных видов медиа, собственной аудитории в соответствии с редакционной политикой [Meyer, Ontrup, Schicha 2000: 189].

И отдельного внимания заслуживает процесс, начинающийся после того, как адаптированный таким образом материал потребляется сетевым обществом [Castells 2010], которое в силу своих принципиальных отличий от общества традиционных медиа воспринимает, обрабатывает и распространяет информацию иначе, так как “сетевые структуры и являются новым мировым порядком, формирующим нормы, правила и регулирующим все стороны общественной и политической жизни” [Кравченко, Подберёзкин 2016].

В итоге мы видим, что после того, как исходный материал проходит каждый из этих этапов, автор инсценирования постепенно теряется, а целенаправленное "воздействие" сменяется задачей произвести "впечатление”. Неотъемлемой же частью инсценирования остается гиперболизация исходного сообщения.

На основе изложенных замечаний автор предлагает следующее определение: инсценирование - это воздействие посредством медиа, результатом которого становится создание определенного образа, ситуации или устойчивой смысловой связи по аналогии с гиперболизированной вымышленной реальностью, “представляемой” на сиене.

\section{ХАРАКТЕРИСТИКА ПОНЯТИЯ: СОЦИОАНТРОПОЛОГИЧЕСКИЙ АСПЕКТ}

С помощью инновационных медиатехнологий инсценирование вошло в повседневность, значительно изменив социальную реальность. “Театральные декорации" и приемы драматического повествования заняли важное место в жизни человека, чего не могло случиться до распространения телевидения и затем интернета. Здесь кроется ключевое отличие инсценирования реальности от традиционного социального конструирования, описанного П. Бергером и Т. Лукманом [Бергер, Лукман 1995]. В частности, медиа перемещают чужие драмы, произошедшие в далеких странах события и личные взгляды других людей в радиус нашего повседневного восприятия. А с ростом популярности онлайн-СМИ понятие “здесь и сейчас" теряет рамки и границы, как и социальная реальность, которая изначально ограничивалась физической близостью и контактами “лицом к лицу". Современные медиа во много крат интенсивнее осуществляют "изменение масштаба, скорости или формы, которое привносится ими в человеческие дела” [Маклюэн 2003: 10]. 
Примечательно, что в работе Бергера и Лукмана медиа получили явно второстепенную роль и упоминались лишь в единичных случаях, тогда как на момент написания книги (1966 г.) они уже занимали важное место в жизни человека. В качестве функции медиа ученые упоминали “подтверждение координат индивидуальной субъективной реальности” [Бергер, Лукман 1995: 70]. Эту функцию они приписывали прессе, однако особого акцента на этом не делали - из чего следует вывод, что на месте газеты могли быть и другие медиа. Кроме того, они придавали равное значение разным жанрам - как прогнозам погоды, статьям, так и рекламным объявлениям. По словам Бергера и Лукмана, разнообразие контента позволяло читателю вернуться в реальный мир и разграничивало сновидения и действительность.

В мире, описываемом Бергером и Лукманом, существовала четкая граница между реальностью повседневной жизни и другими реальностями, так как последние были “конечными областями значений”, отмеченными характерными способами восприятия. Сюда же исследователи относили реальность сновидений или теоретического мышления, а также игры. Примечателен пример театра, который приводился в качестве иллюстрации “переключения между реальностями”: авторы теории подчеркивали, что зритель “переносился” в другой мир в тот момент, когда поднимался занавес, и возвращался к реальности повседневной жизни, когда тот опускался. Предполагалось, что после этого реальность, представленная на сцене, казалась “незначительной и эфемерной” [там же: 20].

Можно с уверенностью сказать, что медиа стали оказывать принципиально иной эффект по сравнению с описанным в “Социальном конструировании реальности”. Реальность повседневной жизни все больше заменяется реальностью медиа, а “значимым другим” может стать собеседник в соцсетях, а не человек из ближайшего окружения. Виртуальная реальность и технологии дополненной реальности целенаправленно вводят в повседневность мир “сновидений”, а границы между действительным и вымышленным стираются. Современный человек не имеет больше четкого понимания реального, поскольку его мир во многом виртуален и интерактивен, а инсценирование присутствует в каждой сфере его жизни.

\section{ХАРАКТЕРИСТИКА ПОНЯТИЯ: ПОЛИТОЛОГИЧЕСКИЙ АСПЕКТ}

Развлекательная составляющая занимает все больше места во всех основных сферах “общества впечатлений”, а медиа и политика в первую очередь следуют данной тенденции, стремясь сделать свой продукт наиболее востребованным. Для отражения этого феномена используется понятие "политейнмент", в рамках которого сочетаются концепции медиадемократии [Schicha 2000] и “общества впечатлений” [Dörner 2001: 40].

Злоупотребление “политейнментом" может привести к негативным последствиям. Если повседневный опыт людей и информационная повестка избирательной кампании слишком далеки друг от друга, возникает угроза разочарования, усталости от политики и, в долгосрочной перспективе, дестабилизации политической системы. Поэтому эффективная, в ценностнорациональном смысле "хорошая" политическая повестка столь же важна, как и успешность инсценирования событий. Если один компонент отсутствует, то вся система сталкивается с серьезными проблемами.

Ориентация на развлечения в СМИ усиливает разрыв в качественных знаниях между “информационной элитой” и “публикой”, которую легко отвлечь 
от темы с помощью шоу и спецэффектов. Телевидение может показывать “реальность", состоящую из поверхностного видеоряда, не относящихся к делу деталей и драматически представленных конфликтов, в которых, как правило, задействованы известные личности. А. Шумхен считает, что речь идет о необходимости "принятия политических решений вопреки средствам массовой информации” [Schümchen 2002: 13].

Требование отделить политику от развлекательной составляющей и драматических эффектов будет неверным: политический дискурс включает в себя не только предмет и содержание, но также компонент публичного представления, который служит легитимации политических действий. Театральный элемент всегда играл важную роль в политической коммуникации, а в рамках политических мероприятий используются преимущественно опосредованные знаки-символы - будь то метафоры, жесты, флаги, эмблемы или слоганы.

Более релевантен в рамках политической коммуникации следующий критерий приемлемости политического инсценирования: на фоне драматургических приемов и смысловой редукции должны оставаться явными и узнаваемыми главная проблематика и ключевые тезисы. Аудитории должны быть предоставлены разные аргументированные точки зрения по каждому вопросу. Тем не менее в процессе инсценирования подобные принципы зачастую не соблюдаются, во многом из-за того, что в политическом дискурсе при передаче информации неизбежно возникает некая форма “эстетической трансформации” [Schicha, Brosda 2002: 91].

\section{СООТНОШЕНИЕ "РЕАЛЬНОГО” И “ИНСЦЕНИРОВАННОГО”}

Также эстетической трансформации в процессе медиатизации подвергаются не только образы политиков и политические дискуссии, но и явления внутренней и международной политической повестки дня. В частности, медиа влияют на восприятие публикой криминальной ситуации: новости о преступлениях воздействуют на оценку реальности. Так, из-за масштабного освещения криминальной хроники в СМИ, вызванного стремлением привлечь больше внимания, реципиенты воспринимают совершенные с особой жестокостью преступления как часть повседневности. Возникает замкнутый круг: зрители чаще потребляют информацию о насилии, а медиа, отвечая потребностям аудитории, уделяют больше внимания сюжетам об убийствах.

В итоге аудитория СМИ, активно освещающих криминальную хронику, уверена, что в обществе именно та ситуация, которую ей преподносят медиа. Например, репрезентативные опросы в Германии показали, что большинство уверено в росте преступности, тогда как по статистическим данным правоохранительных органов этот показатель постоянно снижался на протяжении последних десяти лет. Около $20 \%$ всех криминальных новостей касаются смертей и убийств, при том что реально на них приходится чуть более $0,01 \%$ от общего числа преступлений [Leutheusser-Schnarrenberger 2012: 7].

Влияние на публику трагических и катастрофических событий, таких как террористические акты, в начале века описал Ж. Бодрийяр. Налет на “башни-близнецы” 11 сентября 2001 г., по определению Бодрийяра, стал “абсолютным событием, настоящей 'матерью’ событий, событием в чистом виде, которое концентрирует в себе все другие события, которые никогда еще не происходили” [Бодрийяр 2016: 96]. Ученый отмечал, что, с одной стороны, 
этот теракт стал событием, которое нельзя выдумать или спрогнозировать. С другой стороны, он был парадоксально ожидаемым и, как ни странно, желаемым событием, поскольку удовлетворял неосознанное стремление людей стать свидетелями падения сверхдержавы.

Теракт в качестве “абсолютного оружия зла” заложил в сознании людей ощущение “символической угрозы”, или "глобального инсценирования угрозы терроризма”. Бодрийяр подчеркивает, что в первое время после теракта у людей не было даже приблизительного представления о причинах произошедшего. В итоге информация о теракте в сознании публики закрепилась в виде кадров из СМИ и наложилась на дискуссии, которые велись на фоне теракта. Так теракт превратился в медийное событие, т.е. симулякр, затмивший собой реальные факты.

Понятия, введенные Бодрийяром, отражают механизм инсценирования реальности на глобальном уровне. Отправной точкой для инсценирования становится представление о некотором принципиально новом глобальном кризисе или событии, полученное из СМИ. В ходе обсуждения события в медиа и социальных сетях люди проецируют произошедшее на собственную социальную среду, прогнозируя опасности. Формирующаяся таким образом гиперреальность не поддается привычному порядку, который “может проявить себя лишь в реальном и рациональном” [Бодрийяр 2015]. В обществе, пребывающем в состоянии шока и страха, рождается стремление защититься от подобных кризисов в будущем, готовность изменить ради этой цели привычный жизненный уклад и принять экстренные радикальные меры. Однако расплывчатость гиперреального не позволяет принимать последовательные решения. В итоге действия, порожденные инсценированными рисками, сами приводят к возникновению новых угроз.

Информация, основанная на "мифах о событии”, складывается в сознании человека в такое же неопределенное и гипертрофированное представление о реальности, которое при этом ни на секунду не становится статичным, а претерпевает изменения на фоне новых происшествий и распространения новых идей и мнений. Это состояние, которое Зигмунт Бауман называет “текучей современностью”, подразумевает, что происходит переход от мира, дававшего четкую характеристику событиям и явлениям и имевшего ряд социальных обязательств и условий, к миру текучему, свободному от подобных характеристик и условий. По мнению Баумана, в ходе непрерывного движения возникает новая действительность, люди становятся более мобильными и перестают ощущать, что связаны длительными обязательствами, поскольку все вокруг постоянно меняется. Одной из новых реалий “текучей современности” Бауман называет "исчезновение сил, способных поддерживать вопрос порядка и системы на политической повестке дня” [Бауман 2008: 12].

\section{ИНСЦЕНИРОВАНИЕ КАК ОДНО ИЗ ЦЕНТРАЛЬНЫХ ПОНЯТИЙ ТЕОРИИ РИСКА}

Не имея неизменного - хотя бы на короткий промежуток времени - знания о мире и происходящем вокруг, современный человек вынужден ежесекундно учитывать все риски, о которых он не имеет представления, поскольку их масштаб вырастает в несколько раз усилиями СМИ и социальных сетей. Сделанный им выбор, даже оказавшись “правильным” в конкретный момент, в следующую минуту может стать “неправильным”, поскольку обстоятельства изменились под воздействием поступившей информации.

Ситуация постоянного напряжения и неопределенности приводит к тому, что человек погружается в перманентно тревожное состояние, которое в кри- 
зисные моменты перерастает в чувство паники и страха. Такое положение вещей чрезвычайно выгодно для политических акторов, стремящихся к концентрации власти в своих руках и управлению общественным мнением. В условиях глобального информационного противоборства акторы пространства политической коммуникации из этой ситуации стремятся извлечь преимущества, чтобы воспользоваться кризисной ситуацией и завладеть общественным мнением, предложив людям, парализованным паникой и страхом, конкретную и выполнимую рекомендацию по преодолению возбуждающей страх угрозы [Аронсон, Пратканис 2003: 157].

В наше время политические акторы могут воспользоваться "преимуществами” кризисной ситуации даже тогда, когда ее не существует в реальности. Они учитывают стремление людей к предотвращению чрезвычайных ситуаций и прогнозированию возможных рисков, а затем предлагают план по переустройству общества или даже мирового порядка, который обещает им “защищенность" от будущих катастроф. Инсценирование реальности может использоваться как политическими акторами, стремящимися получить ресурсы власти, так и акторами, уже имеющими эти ресурсы, в том числе непосредственно государственными структурами. Именно за счет инсценирования рисков общество зачастую принимает непопулярные реформы, ограничивающие его свободу, и легитимируются политические режимы, которые в условиях отсутствия инсценированных угроз не смогли бы найти поддержку.

Современное общество, определяемое Ульрихом Беком как “мировое общество риска”, предоставляет политическим акторам пространство для подобных манипуляций. Его особенностью становится воплощение следующей формулы: “глобальный риск есть инсценирование реальности глобального риска” [Beck 2010: 10]. Бек подчеркивает, что решающую роль здесь играет стирание границы между риском как ожидаемой катастрофой и реальной катастрофой. В итоге с помощью воображения и инсценирования будущая катастрофа зачастую превращается в “самоисполняющееся пророчество”.

\section{ВОЗМОЖНОСТЬ СОЗДАНИЯ “РАЦИОНАЛЬНОГО” ПОЛИТИЧЕСКОГО КОНТЕНТА}

В работах, посвященных инсценированию, исследователи [Meyer 2000a; Fischer-Lichte 2001; Kuhn 2000] затрагивают вопрос о его приемлемости в контексте ориентации общества на принципы демократии.

Авторы сходятся в том, что, во-первых, требование отказа от инсценирования в политике бессмысленно в силу символической составляющей политических процессов, а в ходе социальных, коммуникативных и политических трансформаций оно получило более широкое распространение, чем когда-либо ранее. Спрос на подобный контент повысился, поскольку в условиях неопределенности, избытка фоновой информации и неспособности к ее моментальному анализу человек стал полагаться на эмоции, к которым и апеллирует инсценирование. Сложилось общество “новой толпы” [Чугров 2017], требующее простых решений и “желтых" новостей.

Во-вторых, увеличение количества сообщений и каналов коммуникации привело к тому, что в приоритете оказались оперативность, емкость и образность, что усиливает редукцию и упрощение фактов, а это, в свою очередь, упрощает задачу по установлению и навязыванию смыслов. Связи и метафоры, которые были бы неуместны при полном и контекстуальном освещении событий, кажутся людям логичными в редуцированных образах. 
B-третьих, политические акторы, ориентируясь на потребности аудитории, выбирают инсценирование как наиболее простой и действенный способ получить понимание и одобрение электората.

Доминирование инсценирования в информационном пространстве влечет за собой ряд последствий. Среди них - снижение качественного уровня дискурса, поскольку инсценирование не подразумевает дебатов (или в лучшем случае использует уже давно известные аргументы). Процессы, происходящие в сетевом обществе, подчас не соответствуют идеалам демократического принятия решений и формирования мнений. Опасность состоит в том, что в результате идеализации, драматизации и мистификации политических событий в СМИ становится невозможной (или ограничивается) способность общества к критическому мышлению.

Инсценирование перестало быть одним из инструментов управления и легитимации власти и приобрело повсеместный характер, стало доступно не только политикам, но и любым другим акторам, попадающим в поле зрения СМИ и не обладающим специфическими знаниями и навыками. Властные органы потеряли “монополию на политическое инсценирование”, что в некоторой степени говорит о том, что “толпа” уже получила большее влияние на информационное пространство благодаря тому, что “власть структуры оказалась сильнее структуры власти" [Castells 2010].

В результате попыток максимальной визуализации медийного материала, персонализации, присваивания политикам символических ролей, высокопоставленные лица непропорционально часто становятся участниками инсценирования, а политические процессы “исчезают за демонстрируемой политической фигурой” [Schicha, Ontrup 1999: 186].

И, наконец, еще одной опасностью, которую скрывает популярность инсценирования, становится трансформация политического. Несмотря на то, что инсценирование доступно для восприятия большим числом людей и таким образом способствует широкому распространению смыслов, можно заметить, что политика все больше теряет свою политическую сущность. Примером могут быть ток-шоу, в которых политики говорят не о целях и программах, а о семье, хобби и т.п. Сконструированные события и фейковый видеоряд используются, чтобы привлечь внимание, а не вскрыть смысл. "Чем меньше доступного времени и чем меньше доступных денег, тем ниже компетентность и ответственность медиа, тем больше средства массовой информации склонны предлагать инсценирование 'на пустом месте', т.е. театрализацию без политического контента как такового" [Meyer 2000b: 121].

Осознавая все негативные последствия и невозможность отказа от инсценирования, исследователи пытались разработать критерии его оценки. Многие из этих параметров, однако, предполагали, что реципиенты обладают достаточными компетенциями, для того чтобы - как критики во время театральных постановок - распознавать грань между эффектами и реальностью. "Все те же требования, которые аудитория предъявляет к стандартному коммуникационному процессу, такие как информативность и достоверность, она может применять к контенту в рамках инсценирования" [Kuhn 2000: 96]. Однако инсценирование актуальных событий отличается от постановки художественного произведения или от инсценирования исторического события: у реципиента часто нет доступа к фактам из “первоисточника”, а значит, полноценный анализ увиденного ему недоступен. 
Т. Мейер предлагает следующие модальности инсценирования, возлагающие большую часть ответственности на автора контента [Meyer 2000a: 171]:

- узнаваемость основной информационной повестки (заданные темы и структура дискуссии не подлежат искажению в процессе инсценирования);

- театральность должна находиться в подчиненном положении по отношению к рациональности, а информация и аргументы приоритетны по сравнению со средствами инсценирования;

- организаторы инсценирования несут ответственность за долгосрочные последствия своих действий;

- инсценирование ориентируется на дискурс гражданского общества, и необходимо поддерживать связь между инсценируемыми темами и социальным дискурсом;

- инсценирование и его участники должны оставаться в рамках основных ценностей демократического общества.

Эти принципы, опирающиеся на критерии рациональности коммуникации Ю. Хабермаса, все труднее применять в контексте усложнения коммуникации в сетевом обществе. Они подразумевают наличие контролируемого и предсказуемого мира, в котором четко прослеживаются последствия действий, а рациональность и ценности выступают константой как для производителя контента, так и для его потребителя.

Упомянем несколько нюансов, связанных с применением этих критериев.

Прежде всего, учитывая невозможность прогнозирования на длительную перспективу и отслеживания всех взаимосвязей современных коммуникационных процессов, мы видим, что СМИ оказались перед лицом той же “неосведомленности”, что и аудитория. Получая информацию от источника порционно, новостные медиа нередко не имеют полной картины события. На момент появления аналитики интерес к событию уже угасает, и до полноценного обзора произошедшего добирается лишь незначительная часть потребителей новостного контента. Подобная ситуация выгодна СМИ, которые получают большую часть трафика именно на новостных сообщениях.

Второй пункт, непосредственно вытекающий из первого, заключается в практической невозможности “продать” аудитории качественно-рациональный контент в силу отсутствия: 1) оперативности; 2) эффекта “здесь и сейчас”, 3) развлекательного компонента. Аналитические источники поэтому уступают в популярности новостным СМИ, соцсетям и ток-шоу.

И, наконец, логика подразумевает наличие некого центра, способного не только производить инсценирование, но и контролировать его, тогда как в современном информационном пространстве, функционирующем как ризома, это также часто не представляется возможным. Несмотря на то, что предпринимается немало попыток инсценирования “сверху”, т.е. политиками и властными структурами, сам способ подачи материала выбирается с учетом потребностей зрителя и с участием зрителя. Аудитория становится и заказчиком, и производителем, и потребителем инсценированного контента.

Инсценирование как понятие политической социологии не несет само по себе положительных или отрицательных коннотаций, в отличие от фальсификаций. Исходя из трудов Дж. Александера, укажем, что инсценирование (наряду с многими иными социальными реалиями) не имеет качественного, 
ценностного содержания, а получает его лишь в результате означения как процесса кодирования реалий. Категорию “зла” следует рассматривать не как нечто существующее, а как продукт “культуральной и социологической работы”: “Для того чтобы травматическое событие обрело статус зла, необходимо его становление злом. Это вопрос того, как травма входит в знание, как она кодируется" [Alexander 2003: 31-32].

Фриц Кун также не видит принципиальной опасности в инсценировании, утверждая, что она возникает только в том случае, если СМИ поощряют производство низкокачественного манипулятивного контента [Kuhn 2000: 95]. Однако именно этот контент современная аудитория воспринимает охотнее всего. И если во времена доминирования печатной прессы руководители СМИ и журналисты не могли с точностью определить, какой материал стал наиболее читаемым, какой заголовок привлек наибольшее внимание, то онлайн-СМИ эти показатели отслеживают постоянно, и решения принимают зачастую именно на их основе. Немаловажную роль сыграло и появление новостных агрегаторов с их автоматизацией и “нейтральными” алгоритмами, усиливающими конкуренцию СМИ и поощряющими производство “кликабельного" контента.

Такая ситуация не может быть однозначно выгодной ни одному из политических акторов, поскольку в итоге создается почва, на которой одинаково быстро распространяются идеи и истории любой направленности, если они подаются в удобной и привлекательной для аудитории форме.

В результате сегодняшняя медийная картина - с фейками, симулякрами и моральным релятивизмом - в большей степени характеризует аудиторию, демонстрирующую готовность потреблять именно такой контент. Для политиков и СМИ первостепенными становятся популярность, цитируемость и упоминаемость. И лишь при этом условии появляется возможность продвигать политический курс, идеи и программы.

Общество и технологии трансформируются слишком быстро, чтобы социальные и политические институты могли “успевать” за ними и адекватно реагировать на изменения. Вторичность их деятельности по сравнению с процессами, происходящими внутри сетевого общества, отражается в стремлении всячески угодить аудитории. Инсценированная реальность - лишь симптом, свидетельствующий о дисбалансе между старыми и новыми составляющими общества, а не сама болезнь.

DOI: $10.17976 /$ jpps/2019.06.11

\section{STAGING OF POLITICAL REALITY}

\section{V.S. Sorokina ${ }^{1}$}

${ }^{1}$ Moscow State Institute of International Relations (MGIMO University). Moscow, Russia

SOROKINA, Veronika Sergeevna, postgraduate student, Department of International Journalism, MGIMO University, email: vero-nika-vika@mail.ru

Sorokina V.S. Staging of Political Reality. - Polis. Political Studies. 2019. No. 6. P. 145-158. (In Russ.) https://doi. org/10.17976/jpps/2019.06.11

Received: 30.05 .2019 . Accepted: 28.08 .2019

Abstract. The term 'staging', which appeared in the 1920s and 1930s as part of the theatrical vocabulary, acquired a new meaning with the advent of new media. Today, this concept reflects the invasion of 
dramaturgical principles, both in the everyday life of each person, and in global political processes. Using methodologies developed by the classics of political sociology and communication science (Baudrillard, Habermas, McLuhan) and modern researchers (Fischer-Lichte, Meyer, Schicha), the author shows how, as a result of the staging, the border between the real and the imagined is blurred. This can later be used for manipulating public opinion. The article discusses historical examples of the 'dramatization of reality' and its features at the present stage, and also analyzes the processes that create conditions for the popularization and widespread use of dramatization as well as its covered mechanisms. The author concludes that, amidst the growth of irrationality and uncertainty in society and the increasing role of the masses in shaping the information agenda, it is they, and not individual actors and ruling elites, who become the main 'customer' of the staged reality. At the same time, it becomes more and more difficult to neutralize the negative effects of the staging, since it has more than a single source and avoids control under current conditions.

Keywords: staging, symbolic politics, political reality; information space, mass media.

\section{References}

Alexander J.C. 2003. The Meanings of Social Life: A Cultural Sociology. Oxford: Oxford University Press. Beck U. 2010. World at Risk. Cambridge: Polity Press.

Burke P. 1993. Ludwig XIV. Die Inszenierung des Sonnenkönigs. Berlin: Wagenbach.

Castells M. 2010. The Rise of the Network Society. $2^{\text {nd }}$ ed. Oxford: Wiley-Blackwell.

Dörner A. 2001. Politainment. Politik in der medialen Erlebnisgesellschaft. Frankfurt am Main: Suhrkamp Verlag.

Edelman M. 1976. Politik als Ritual. Die symbolische Funktion staatlicher Institutionen und politischen Handelns. Frankfurt am Main: Campus Verlag.

Entman R. 1993. Framing: Towards a Clarification of a Fractured Paradigm. - Journal of Communication. Vol. 43. No. 3. P. 51-58.

Fischer-Lichte E. 1998. Inszenierung und Theatralität. - Willems H., Jurga M. (Hg.) Inszenierungsgesellschaft. Opladen: VS Verlag für Sozialwissenschaften. S. 81-90.

Fischer-Lichte E. 2000. Theatralität und Inszenierung. - Fischer-Lichte E. (Hg.) Inszenierung von Theatralität. Tübingen: Francke. S.11-23. https://doi.org/10.1007/978-3-322-89797-8_3

Hoffmann J. Sarcinelli U. 1999. Politische Wirkungen der Medien. - Wilke J. (Hg.) Mediengeschichte der Bundesrepublik Deutschland. Köln: Böhlau Verlag. S. 720-751.

Kaase M. 1998. Demokratisches System und die Mediatisierung von Politik. Seite 22 bis 51. - Sarcinelli U. (Hg.) Politikvermittlung und Demokratie in der Mediengesellschaft. Bonn: VS Verlag für Sozialwissenschaften. S. 22-51.

Kuhn F. 2000. Inszenierung und Glaubwuerdigkeit. - Siller P., Pitz G. (Hg.) Politik als Inszenierung. Zur Ästhetik des Politischen in Medienzeitalter. Baden-Baden: Nomos-Verlag. S. 94-95.

Leutheusser-Schnarrenberger S. 2012. Die Macht der Medien ist kein Selbstzweck. - Hestermann T. (Hg.) Von Lichtgestalten und Dunkelmännern. Wiesbaden: VS Verlag für Sozialwissenschaften. S. 7-9. https:// doi.org/10.1007/978-3-531-18991-8_1

Meyer T. 2000a. Angemessenheitsbedingungen für die mediale Inszenierung des Politischen. - Schicha C., Brosda C. (Hg.) Medienethik zwischen Theorie und Praxis. Münster: LIT. S. 167-172.

Meyer T. 2000b. Die Theatralität der Politik. - Siller P., Pitz. G. (Hg.) Politik als Inszenierung. Zur Ästhetik des Politischen in Medienzeitalter. Baden-Baden: Nomos-Verlag. S. 117-122.

Meyer T. 2001. Mediokratie. Die Kolonisierung der Politik durch die Medien. Frankfurt am Main: Suhrkamp Verlag.

Meyer T., Ontrup R., Schicha C. 2000. Die Inszenierung des politischen Welt-Bildes. Politikinszenierungen zwischen medialem und politischem Eigenwert. - Fischer-Lichte E., Pflug I. (Hg.) Inzenierung von Authentizität. Tübingen: Francke. S. 183-208.

Schicha C. 2000. Offentlichkeit unter Medienbedingungen. - Schicha C., Brosda C. (Hg.) Medienethik zwischen Theorie und Praxis. Münster: LIT. S. 173-194.

Schicha C., Brosda C. 2002. Politikvermittlung in Unterhaltungsformaten. Medieninszenierungen zwischen Popularität und Populismus. Münster: LIT. 264 S. https://doi.org/10.1007/s11616-003-0128-z

Schicha C. 2003. Die Theatralität der politischen Kommunikation, Medieninszenierungen am Beispiel des Bundestagswahlkampfes 2002. Münster: LIT.

Schicha C., Ontrup R. 1999. Medieninszenierungen im Wandel. Interdisziplinäre Zugänge. Münster: LIT. 
Schümchen A. 2002. Politikvermittlung zwischen Information und Unterhaltung - Emotionen statt Argumente. - Forum Medienethik. No. 2. S. 7-13.

Aronson E., Pratkanis A.R. 2003. Age of Propaganda: The Everyday Use and Abuse of Persuasion. (Russ. ed.: Pratkanis A.R., Aronson E. Epoha propagandy: Mekhanizmy ubezhdeniya, povsednevnoe ispol'zovanie i zloupotreblenie. St. Petersburg: Praim-EVROZNAK).

Baudrillard J. 2015. Simulation et simulacres. (Russ. ed.: Baudrillard J. Simulyatsiya i simulyakry. Moscow: POSTUM).

Baudrillard J. 2016. The Spirit of Terrorism. (Russ. ed.: Baudrillard J. Duh terrorizma. Vojny v zalive ne bylo. Moscow: Ripol Klassik).

Baumann Z. 2005. Liquid Life. (Russ. ed.: Baumann Z. Tekuchaya sovremennost'. St. Petersburg: Piter).

Berger P.L., Luckmann T. 1995. The Social Construction of Reality: A Treatise in the Sociology of Knowledge. (Russ. ed.: Berger, P. L., Luckmann T. Social'noe konstruirovanie real'nosti. Traktat po sociologii znaniya. Moscow: Medum; Academia Centr).

Chugrov S.V. 2017. Post-truth: Transformation of Political Reality or Self-Destruction of Liberal Democracy? - Polis. Political Studies. No. 2. P. 42-59. (In Russ.) https://doi.org/10.17976/jpps/2017.02.04

Kravchenko S.A., Podberezkin A.I. 2016. Social Nets as a New Factor of System Security in Russia in the $21^{\text {st }}$ Century. - MGIMO Review of International Relations. Vol. 51. No. 6. P. 14-23. (In Russ.)

McLuhan M. 2001. Understanding Media. (Russ. ed.: McLuhan M. Ponimanie media: Vneshnie rasshireniya cheloveka. Moscow; Zhukovskij: KANON-press-C, Kuchkovo pole).

Simvolicheskaya politika [Symbolic Politics]. 2012. Ed. By O.Yu. Malinova. Vyp. 1: Konstruirovanie predstavlenii o proshlom kak vlastnyi resurs [Constructing Representations of the Past as an Imperious Resource]. Moscow.

\section{Литература на русском языке}

Аронсон Э., Пратканис Э.Р. 2003. Эпоха пропаганды: Механизмы убеждения, повседневное использование и злоупотребление. СПб.: Прайм-ЕВРОЗНАК.

Бауман 3. 2008. Текучая современность. СПб.: Питер.

Бергер П., Лукман Т. 1995. Социальное конструирование реальности. Трактат по социологии знания. М.: Медум; Academia Центр.

Бодрийяр Ж. 2015. Симуляция и симулякры. М.: ПОСТУМ.

Бодрийяр Ж. 2016. Дух терроризма. Войны в заливе не было. М.: Рипол Классик.

Кравченко С.А., Подберёзкин А.И. 2016. Социальные сети как качественно новый фактор системной безопасности России в XXI веке. - Вестник МГИМО-Университета. Т. 51. № 6. С. 14-23.

Маклюэн М. 2003. Понимание медиа: Внешние расширения человека. М.; Жуковский: КАНОНпресс-Ц, Кучково поле.

Символическая политика. 2012. Отв. ред.: Малинова О.Ю. Вып. 1: Конструирование представлений о прошлом как властный ресурс. М.

Чугров С.В. 2017. Post-truth: трансформация политической реальности или саморазрушение либеральной демократии? - Полис. Политические исследования. № 2. C. 42-59. https://doi.org/10.17976/ jpps/2017.02.04 